\title{
Planning documents and sustainable development of a commune in Poland
}

\author{
A. Stacherzak, M. Hełdak \& B. Raszka \\ Department of Spatial Management, \\ Wroclaw University of Environmental and Life Sciences, Poland
}

\begin{abstract}
This paper points at the role of the planning document defining spatial policy in creating the sustainable development of a commune. The study serves to analyse whether the planning of spatial development of communes under environmental protection in the vicinity of the city of Wrocław is performed in accord with the functioning of the natural environment and fosters the sustainable development of villages. The evaluation was performed based on a set of approved indicators for evaluating sustainable development with regard to environmental order, as well as approved indicators for the sustainable development of the spatial policy on a local level.
\end{abstract}

Keywords: sustainable development, spatial policy of a commune.

\section{Introduction}

Defining sustainable development as "a process aimed at the realisation of developmental aspirations of the current generation in a way which would make it possible for future generations to realise the same goal," [1] the role of planning documents in the creation of sustainable development in a commune seems to be unquestionable. The term "sustainable development" is rarely associated with business, but it is an important aspect of such. For decades the problem of corporate social responsibility has been a subject of deliberation among both theoreticians and practitioners of management [2].

In Poland, instruments for planning and localisation are still decisive tools when it comes to shaping space that is filled with anthropogenic objects $[3,4]$.

The spatial development of Poland on a local level is undertaken based on the spatial policy defined in the Study of Determinants and Directions for the Spatial 
Management of a Commune document. The primary tasks related to spatial policy include both the determining of goals for such a policy, as well as the means and methods for their realisation. The tool used for the realisation of a spatial policy included in the Study of Determinants and Directions for the Spatial Management of a Commune is the local spatial development plan.

Taking into account the principles for the creation of a commune's developmental policy and its realisation by local authorities, one might say that planning is one of the most important tools utilised in the management process, and that it is also used as a tool which forms the future image of the country and the region, and, under Polish conditions, is decisive for the quality of human life and the functioning of the natural environment [5-7].

In their activities regarding spatial planning, urban planners seek the main tool for creating the spatial sphere, in order to significantly influence the remaining spheres of sustainable development [8].

Sustainable development policies typically encompass three main themes: economic, environmental and social, but according to the European Landscape Convention (Council of Europe, 2000) and UNESCO's Universal Declaration on Cultural Diversity (UNESCO, 2002), there is a fourth - cultural - element to sustainability. When discussing the preamble to the European Landscape Convention, Prieur [4] refers to its promotion of: "all four ingredients of sustainable development (social, ecological economic and cultural improvement)" [10].

The role Environmental Impact Assessment in the development process is recognised as an integral part of the planning and decision-making process. Its strength lies in its potential for analysing the associated environmental issues and for improving the siting, layout and design of a particular scheme. The assessment of landscape and visual effects is an essential part of this process [11].

The goal of this paper is to emphasise the role of the planning document which defines the spatial policy in Poland in creating sustainable development of communes under legal protection, as well as to evaluate the sustainable development of communes using approved indicators, in the sphere of environmental order and the spatial policy realised on a local level.

The currently available studies by the authoresses of this paper analysed the sustainable development of tourist attractive communes, as well as the influence of the regulations of the local plan on the natural environment of tourist towns. The publications in question [5,9] were not prepared using the approved indicators of sustainable development. That is why this study undertakes the evaluation of the approved spatial policy in the sphere of sustainable development, based on approved indicators.

\section{Methodology}

Numerous studies have been undertaken in Europe in an attempt to formulate a system of indicators for the monitoring of sustainable development on a local level (commune). According to Kozłowski [7], the following sets of indicators 
have the highest comparative value for the construction of a substantive structure of a local module of sustainable development indicators in Poland:

- Common European Sustainable Development Indicators (10 indicators);

- Urban Audit indicators (21 groups of indicators);

- Environmental Pressure indicators (TEPI);

- pressure indicators (the Ecological Footprint);

- the HABITAT Agenda indicators;

- sets of indicators utilised in specific local units (The Ghent Barometer for Sustainable Development), local indicators for the evaluation of sustainable development in local British territorial units (in London: LITMUS, Strathclyde).

In Poland, the various indicators which could potentially serve the monitoring of sustainable development on a local level are registered by the Central Statistical Office. Information gathered in the Regional Data Bank, currently the Local Data Bank, could serve as a basis for the retrieval of information on sustainable development. Unfortunately, the database still does not register all the indicators which could be helpful in evaluating sustainable development on the level of the commune (i.e. the local level).

An important feature of the research, also performed in Poland, is the creation of indicator groups according to the Pressure-State-Response (P-S-R) principle. One of the first institutions which set out to introduce a set of environmental indicators was the Organisation for Economic Co-operation and Development (OECD, 1991, 1993). Intensive work with indicators was also performed by the World Health Organisation (WHO) in 1993 and 1994. The OECD introduced the division to indicators for environmental pressure, conditions (quality state) of the environment and (human) response to environmental problems - P-S-R in short - utilised in further research on indicators [after 4]. One of the most commonly used indicators of sustainable development, used in the Agenda 21, was introduced by the United Nations Conference on Sustainable Development (UNCSD) in the year 1996. Some of the indicator systems are particularly complex and hard to employ under Polish conditions.

The authors of the study focused on the evaluation of the environmental order in its dynamic model and the evaluation of sustainable development in the context of the spatial policy realised by communes located in the vicinity of Wrocław. The indicators employed in the study have been described in tables 1 and 2. The communes selected for research are also partially under environmental protection, in the form of natural landscape parks (a form of environmental protection used in Poland). Some of the measures (indicators) used in the study are often retrieved only by means of direct research; it is also rarely possible to retrieve them from a given commune office. The data for spatial policy has been formulated on the basis of measurements performed in the selected areas for the realisation of various functions in the document delineating the spatial policy of each commune. 
Table 1: Local indicators used in the study of environmental order, based on research conducted in Poland.

\begin{tabular}{|c|c|c|c|}
\hline No. & Indicator name/definition & Unit & Data source \\
\hline 1. & $\begin{array}{l}\text { Share of agricultural land area in the total } \\
\text { area of the commune }\end{array}$ & $\%$ & CSO - LDB \\
\hline 2. & $\begin{array}{l}\text { Agricultural land area per commune } \\
\text { resident }\end{array}$ & $\%$ & CSO - LDB \\
\hline 3. & $\begin{array}{l}\text { Share of area for communication in the } \\
\text { total area of the commune }\end{array}$ & $\%$ & CSO - LDB \\
\hline 4. & $\begin{array}{l}\text { Share of housing area in the total area of } \\
\text { the commune }\end{array}$ & $\%$ & CSO - LDB \\
\hline 5. & Share of housing area per 1 resident & ha/resident & CSO - LDB \\
\hline 6. & Share of recreational parks per 1 resident & ha/resident & CSO - LDB \\
\hline 7. & $\begin{array}{l}\text { Area of cultivated and community green } \\
\text { areas per } 1 \text { resident }\end{array}$ & ha/resident & CSO - LDB \\
\hline 8. & Expenses for green areas per 1 resident & $\mathrm{zl}$ & CSO - LDB \\
\hline 9. & $\begin{array}{l}\text { Share of agricultural holdings in the total } \\
\text { area of the commune }\end{array}$ & $\%$ & CSO - LDB \\
\hline 10. & $\begin{array}{l}\text { Share of people employed in agriculture } \\
\text { in the total number of the employed }\end{array}$ & $\%$ & CSO - LDB \\
\hline 11. & $\begin{array}{l}\text { Losses in agricultural land in comparison } \\
\text { to previous time period }\end{array}$ & $\%$ & CSO - LDB \\
\hline 12. & $\begin{array}{l}\text { Share of legally protected areas of } \\
\text { exceptional environmental value in total } \\
\text { area }\end{array}$ & $\%$ & CSO - LDB \\
\hline 13. & $\begin{array}{l}\text { Share of forest areas in the total area of } \\
\text { the commune }\end{array}$ & $\%$ & CSO - LDB \\
\hline 14. & $\begin{array}{l}\text { Population density of the village's } \\
\text { developed area per } 1 \mathrm{~km}^{2}\end{array}$ & $\begin{array}{c}\text { no. of } \\
\text { residents per } \\
1 \mathrm{~km}^{2} \\
\end{array}$ & CSO - LDB \\
\hline 15. & $\begin{array}{l}\text { Population density of the village area in } \\
\text { total per } 1 \mathrm{~km}^{2}\end{array}$ & $\begin{array}{c}\text { no. of } \\
\text { residents per } \\
1 \mathrm{~km}^{2} \\
\end{array}$ & CSO - LDB \\
\hline 16. & $\begin{array}{l}\text { Share of buildings connected to the } \\
\text { water-supply system in the total number } \\
\text { of buildings }\end{array}$ & $\%$ & CSO - LDB \\
\hline 17. & $\begin{array}{l}\text { Share of buildings connected to the } \\
\text { sewage system in the total number of } \\
\text { buildings }\end{array}$ & $\%$ & CSO - LDB \\
\hline 18. & $\begin{array}{l}\text { Relation between the length of the } \\
\text { sewage system and water-supply system } \\
\text { in the village }\end{array}$ & $\begin{array}{l}1: 1 \\
(1)\end{array}$ & CSO - LDB \\
\hline 19. & Share of residents using sewage plants & $\%$ & CSO - LDB \\
\hline 20. & $\begin{array}{l}\text { Unpurified waste channelled into waters } \\
\text { and soil }\end{array}$ & $\mathrm{m}^{3}$ & CSO - LDB \\
\hline
\end{tabular}

Source: Own elaboration using Borys [12], Hełdak [13]. 
Table 2: Indicators of sustainable development approved for the evaluation of the spatial policy realised in the studied communes.

\begin{tabular}{|c|c|c|c|}
\hline Lp. & Indicator name/definition & Unit & Data source \\
\hline 1. & $\begin{array}{l}\text { Degree of commune areas covered by } \\
\text { spatial development plans }\end{array}$ & $\%$ & RDB \\
\hline 2. & $\begin{array}{l}\text { Area of terrain planned for housing } \\
\text { construction in the spatial policy per } 1 \\
\text { resident }\end{array}$ & $\mathrm{m}^{2}$ & $\begin{array}{c}\text { Own } \\
\text { calculations }\end{array}$ \\
\hline 3. & $\begin{array}{l}\text { Area of terrain planned for economic } \\
\text { activity in the spatial policy per } 1 \text { resident }\end{array}$ & $\mathrm{m}^{2}$ & $\begin{array}{c}\text { Own } \\
\text { calculations }\end{array}$ \\
\hline 4. & $\begin{array}{l}\text { Share of areas planned for change in } \\
\text { purpose for residential-service purpose } \\
\text { accepted in the spatial policy of the } \\
\text { village, in total area }\end{array}$ & $\%$ & $\begin{array}{c}\text { Own } \\
\text { calculations }\end{array}$ \\
\hline 5. & $\begin{array}{l}\text { Share of areas planned for change in } \\
\text { purpose for general construction } \\
\text { (excluding tourism), accepted in the } \\
\text { spatial policy of the village, in total area }\end{array}$ & $\%$ & $\begin{array}{c}\text { Own } \\
\text { calculations }\end{array}$ \\
\hline 6. & $\begin{array}{l}\text { Planned area for construction vs. } \\
\text { currently built-up area }\end{array}$ & $1: 1$ & $\begin{array}{c}\text { Own } \\
\text { calculations }\end{array}$ \\
\hline 7. & $\begin{array}{l}\text { Area of terrain planned for afforestation } \\
\text { in the spatial policy }\end{array}$ & $\mathrm{Ha}$ & $\begin{array}{c}\text { Own } \\
\text { calculations }\end{array}$ \\
\hline 8. & $\begin{array}{l}\text { Share of areas planned for afforestation in } \\
\text { the spatial policy in the total area of the } \\
\text { commune }\end{array}$ & $\%$ & $\begin{array}{c}\text { Own } \\
\text { calculations }\end{array}$ \\
\hline 9. & $\begin{array}{l}\text { Smallest distance of built-up area from } \\
\text { the forest }\end{array}$ & $\mathrm{m}$ & $\begin{array}{c}\text { Own } \\
\text { observations }\end{array}$ \\
\hline 10. & $\begin{array}{l}\text { Smallest distance of built-up area from } \\
\text { the river with its biological cover }\end{array}$ & $\mathrm{m}$ & $\begin{array}{c}\text { Own } \\
\text { observations }\end{array}$ \\
\hline
\end{tabular}

Source: Own elaboration using Hełdak [13].

The environmental area evaluation has been performed throughout a period of 10 years, in 5 year-long intervals, with three measurement stages: 2000, 2005 and 2010. Previous data is unavailable. The evaluation of the sustainable development of the spatial policy realised in the studied communes has been performed on the basis of approved documents for the study of determinants and directions for their spatial management. Data for the indicated features has been gathered in comparative tables. Research was conducted in communes localised in the Wrocław poviat, including the communes Joranów Śląski, Mietków, Kąty Wrocławskie and Sobótka, localised partially within the borders of natural landscape parks, and remaining in Wrocław's area of influence.

\section{The problem of space seizure in the studied communes}

Wrocław has a population of around 650 thousand, and is located in the southwest of Poland. 
The city is a centre for economic and cultural life in the region and the capital of the Lower Silesia. The communes analysed (Sobótka, Mietków, Kąty Wrocławskie, Jordanów Śląski) are located in the vicinity of the city's administrative border. The city itself is the source of a number of changes occurring in those communes. Among the determinants for the direction of changes, urbanisation - or rather suburbanisation - is of decisive importance. Suburbanisation processes are defined as migrations of people from city centres to the peripheries. Suburbanisation is also considered a result of migration, mostly of wealthier groups, from run-down central districts to the suburbs, which allow everyday excursions to work in the centre due to their remote location, concurrently offering substantially better living conditions than those in the previous place of residence [14]. According to other authors, including Berry [15] and Klaassen and Paelinck [16], is related to the decrease in population density in city centres, and the increase in density in the suburbs, with positive migration balance for the entire urban agglomeration maintained.

The studied communes show an increase in environmental pressure due to the seizure of free space. Comfortable access and lower costs of building a house outside of the city encourage people to eagerly move into communes localised in the vicinity of Wrocław. Similarly, production and service investments are cheaper outside of the city. The shift of agricultural land towards urbanised land is mostly observed in order to realise housing or production-services construction projects. On the other hand, the local authorities responsible for the spatial policy have the power to allot large portions of agricultural land for the purpose of construction, and often do so in order to attract investors. The spatial policy in Poland is realised on the local level and it the commune itself is responsible for its formulation, with real estate tax income contributing to the commune's budget.

The problem is especially severe since any person who owns a piece of land in Poland, regardless of its area, can be an investor if the local spatial plan, formulated on the basis of the spatial policy, or a planning permission allows it. This leads to an entire group of investors, whose only aim is the maximisation of their revenues, often blatantly against any environmental protection policies.

\section{Changes in the environment studied on the basis of the approved indicators}

The analyses of environmental order in the communes have been performed in their dynamic models, according to the approved indicators. Due to the size of data gathered for the purpose of the study, the data has been excluded from this paper. The research showed that agricultural land in each commune constitutes a substantial part of the total area of the communes (from $68.42 \%$ in Sobótka to 86.54 in Jordanów Śląski). Along with other means of environmentally friendly land use (forests, open water) they constitute a major area in each commune, with $91.85 \%$ in Sobótka, 90.00\% in Jordanów Śląski, 93.05\% in Mietków and $90.11 \%$ in Kąty Wrocławskie. It seems that the current method of terrain use in the communes is beneficial for the maintaining of environmental order. The 
registered dynamics of change in the share of housing areas did not reveal any violent appropriation of space for urban purposes, with the changes themselves maintained within the $0.1 \%$ level in each commune. These changes, however, are not always registered in the land and property register - the basis for the classification of land use in Poland.

An increase in population in each commune is noticeable, which reflects the changes in population density. In the last 5 years in the Kąty Wrocławskie commune, the population density increased from 100 to 111 people for $1 \mathrm{~km}^{2}$; 91 to 93 in Sobótka. The number of people working in agriculture is diminishing, which shows the residents leaving to find other means of earning money. The highest share of agricultural workers has been noted in Mietków (17\% in 2000), in Jordanów Śląski (13\%), in Kąty Wrocławskie (5\%) and in Sobótka (4\%). This amount is decreasing in the following years.

Water and sewage management, as well as the amount of waste channelled into water and soil, constitute a separate issue analysed in the study. Currently, about $90 \%$ of residents in each commune are connected to the water-supply system, with even $96 \%$ in Jordanów. This number has been increasing throughout the period of the years studied.

Unfortunately, there is still a large disproportion between the number of residents using the water-supply system and the number of residents using the sewage system. The share of citizens using the sewage system has been estimated below (Figure 1).

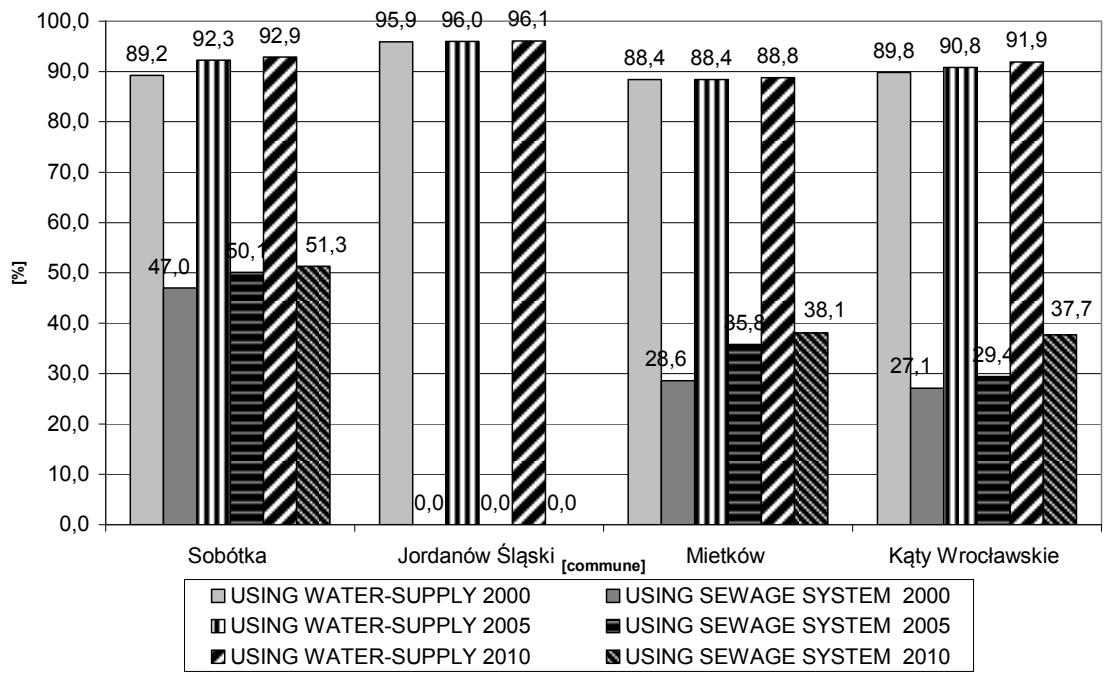

Figure 1: The share of citizens using the sewage system in selected communes in the years 2000, 2005, 2010. 
There is no sewage in Jordanów Śląski, whereas in the remaining communes (Kąty Wrocławskie, Mietków and Sobótka), the share of residents expelling waste into the sewage system connected to a sewage plant is on the increase. In 2010 it was highest in Sobótka.

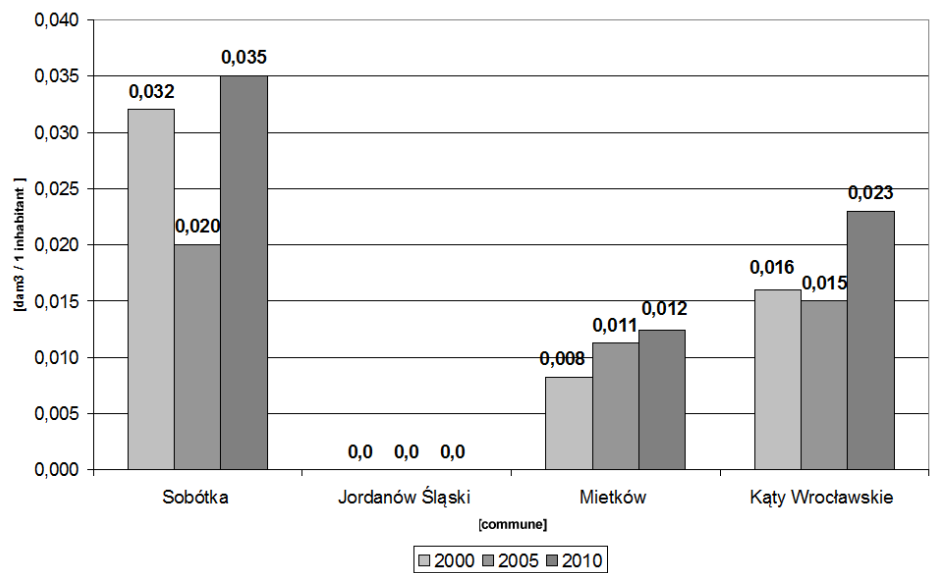

Figure 2: The share of sewers channelling unpurified waste into surface waters or soil, per 1 resident in the years 2000, 2005, 2010.

Research showed that the sewers which require purification, connected to surface waters or the soil, are not monitored in the Jordanów Śląski commune, which does not mean that they do not exist there. In the remaining communes, their amount increased from 2000 to 2010. The greatest increase has been noted in the Kąty Wrocławskie commune.

In the presented state of sustainable development in the studied communes with regard to environmental order, the situation of the Katty Wrocławskie commune seems to be the least favourable. When it comes to water and sewage management, Jordanów Śląski is the least favourable.

\section{Spatial development plans for the communes}

The planning of future spatial development of communes remains a specific issue in the context of protecting grounds from investment. The authorities of the communes around Wrocław wish to meet social expectations by planning the development of urban areas on huge amounts of land currently used for agriculture.

The planned new residential-service buildings could probably be fully occupied only if the number of residents grows fourfold (in Sobótka) or even ninefold (in Kąty Wrocławskie), which seems to be unrealistic, even taking into account the positive migration balance onto suburban areas (table 3 ). 
Table 3: The value of approved indicators of sustainable development for the spatial policy realised in the studied communes.

\begin{tabular}{|c|c|c|c|c|c|c|}
\hline \multirow[b]{2}{*}{$\begin{array}{l}\text { Table } \\
\text { No. }\end{array}$} & \multirow[b]{2}{*}{ Indicator name/definition } & \multirow[b]{2}{*}{ Unit } & \multicolumn{4}{|c|}{ Commune } \\
\hline & & & Sobótka & Jordanów & Mietków & $\begin{array}{l}\text { Kąty } \\
\text { Wrocław } \\
\text { skie }\end{array}$ \\
\hline 1. & $\begin{array}{l}\text { Degree of commune areas } \\
\text { covered by spatial } \\
\text { development plans }\end{array}$ & $\%$ & 76.90 & 17.90 & 99.85 & 100 \\
\hline 2. & $\begin{array}{l}\text { Area of terrain planned for } \\
\text { housing construction in the } \\
\text { spatial policy per } 1 \text { resident }\end{array}$ & $\mathrm{m}^{2}$ & 1284.65 & 1436.96 & 570.40 & 1597.70 \\
\hline 3. & $\begin{array}{l}\text { Area of terrain planned for } \\
\text { economic activity in the } \\
\text { spatial policy per } 1 \text { resident }\end{array}$ & $\mathrm{m}^{2}$ & 506.90 & 947.09 & 197.04 & 1033.00 \\
\hline 4. & $\begin{array}{l}\text { Share of areas planned for } \\
\text { change in purpose into } \\
\text { residential-service purpose } \\
\text { accepted in the spatial policy } \\
\text { of the village, in total area }\end{array}$ & $\%$ & 11.98 & 7.77 & 2.64 & 18.55 \\
\hline 5. & $\begin{array}{l}\text { Share of areas planned for } \\
\text { change in purpose for } \\
\text { general construction } \\
\text { (excluding tourism), } \\
\text { accepted in the spatial policy } \\
\text { of the village, in total area }\end{array}$ & $\%$ & 16.71 & 12.89 & 3.60 & 30.55 \\
\hline 6. & $\begin{array}{l}\text { Planned area for } \\
\text { construction vs. currently } \\
\text { built-up area }\end{array}$ & $1: 1$ & $4.83: 1$ & $3.02: 1$ & $2.34: 1$ & $9.43: 1$ \\
\hline 7. & $\begin{array}{l}\text { Area of terrain planned for } \\
\text { afforestation in the spatial } \\
\text { policy }\end{array}$ & ha & 0.00 & 82.00 & 86.50 & 0.00 \\
\hline 8. & $\begin{array}{l}\text { Share of areas planned for } \\
\text { afforestation in the spatial } \\
\text { policy in the total area of the } \\
\text { commune }\end{array}$ & $\%$ & 0.00 & 1.45 & 1.03 & 0.00 \\
\hline 9. & $\begin{array}{l}\text { Smallest distance of built-up } \\
\text { area from the forest }\end{array}$ & $\mathrm{m}$ & 0 & 5.00 & 0 & 5.00 \\
\hline 10. & $\begin{array}{l}\text { Smallest distance of built-up } \\
\text { area from the river with its } \\
\text { biological cover }\end{array}$ & $\mathrm{m}$ & 10.00 & 10.00 & 10.00 & 10.00 \\
\hline
\end{tabular}

Source: own elaboration.

There exist communes in which more than $10 \%$ of area is planned to be redeveloped for residential-service purposes, with biologically active surfaces being sealed. Areas of economic activity (production, bases, storages) included, this value reaches even $30.00 \%$ of the entire area of the commune in Katy Wrocławskie, and $16.70 \%$ in Sobótka. This data is very unsettling. The Mietków commune achieves favourable results in the evaluation of the sustainable 
development of its spatial policy. From among the four communes studied it seems to enjoy the most sensible land management.

The areas of lands used for housing estates have been included in Figure 3 along with the area of lands designated for residential-service and economic activity in spatial policy plans.

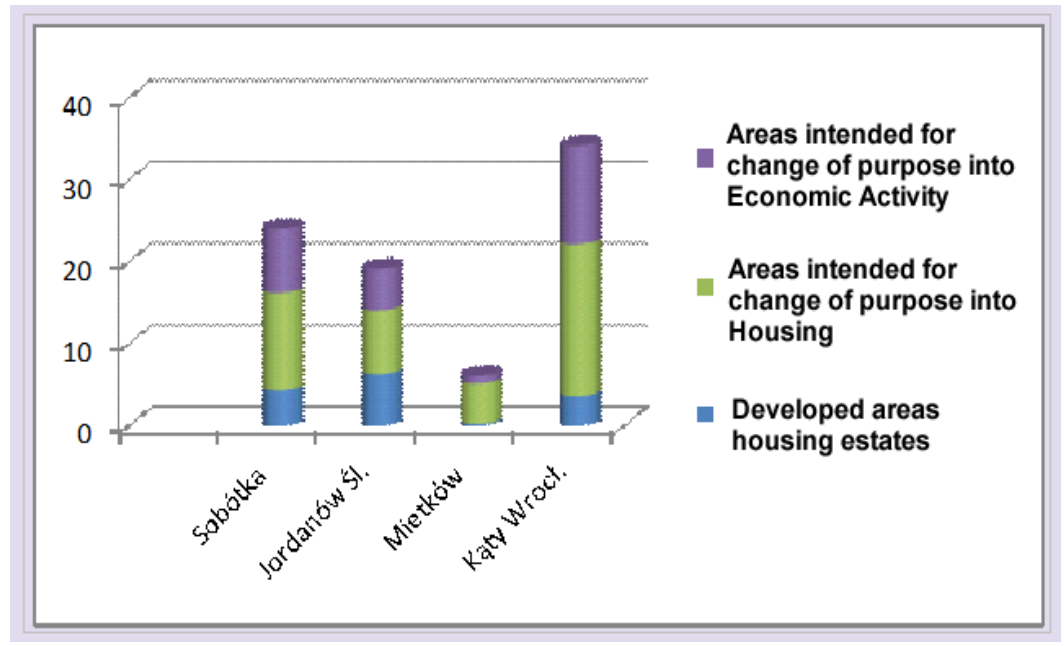

Figure 3: The share of land designated for new construction in spatial policy plans vs. the current land use in the studied communes.

It is estimated that there will be an increase of construction development areas in communes when compared to the current level of investment. Kąty Wrocławskie can again be considered as the commune in which the planned amount of changes towards the urbanisation of the area is the highest.

\section{Conclusions}

This paper served to analyse whether the planning of the spatial development of communes under environmental protection in the vicinity of Wrockaw is conducted in accordance with the functioning of the natural environment and whether it fosters the sustainable development of the villages. The evaluation has been performed using approved indicators of changes in the spatial development of villages.

The amount of vast areas designated for residential-service construction purposes is astounding. Kąty Wrocławskie holds the current record, allotting an area nine times larger than the current land area used for housing estates, for residential-service.

In order to restrict such insensible decisions by local authorities, one should introduce limitations to e.g. the maximum area of new lands for housing per 1 resident. 
Planning documents, including the Study of Determinants and Directions for the Spatial Management of a Commune, do not guarantee the sustainable development of communes. The primary reason for that may come from a conflict of interests: on the one hand, the commune is a guardian of environmental protection and the realisation of spatial development, but on the other hand, it has to fulfil its own tasks, and those require sufficient financial sources. This is the reason why planning documents focus to such a large extent on the development of functions which will bring future revenue in the form of local taxes.

\section{Acknowledgement}

The research has been conducted as part of a research project entitled "Ecosystem services in the environmental development of the Wrocław poviat communes in the context of communes located in landscape parks. Modelling changes - theoretical and practical assumptions." Registration number: N N305 103840.

\section{References}

[1] Our Common Future. United Nations. World Commission on Environment and Development, under the leadership of Gro Brundtland, 1987.

[2] Dobrowolski J. W. Preface. Polish Journal of Environmental Studies. Vol. 17, No. 3A 2008.

[3] Kistowski M. Regional Model for Sustainable Development and Environmental Protection in Poland in the Light of Voivod Development Strategies. Gdańsk University, Bogucki Publishing. Gdańsk - Poznań, 2003. [In Polish]

[4] Hełdak M. Planning Documents and Sustainable Development of a Commune. Polish Journal of Environmental Studies. Vol. 18, No. 3A, 2009, s. 100-107. Olsztyn 2009.

[5] Prieur M. Landscape and social, economic, cultural and ecological approaches: preamble to the convention, in: Landscape and Sustainable Development: Challenges of the European Landscape Convention (Strasbourg: Council of Europe Publishing), 2006.

[6] Davison F. Urban Management Studies. Unpublished materials for managing cities. ICURP, Szczecin University of Technology. 1995.

[7] Kozłowski S. The future of eco-development. KUL Publishing. 197, 586, 2005. [in Polish]

[8] Pęski W. Managing the sustainable development of the city. Arkady. 20, 294, 1999. [in Polish]

[9] Hełdak M., Raszka B. (2011): Prognosis of Natural Environment Transformations Resulting from Spatial Planning Solutions. Polish Journal of Environmental Studies. Vol. 20, No. 6, 2011, s. 1513-1518. 
[10] Owen S., Sarlöv, Herlin I., (2009). A Sustainable Development Framework for a Landscape of Dispersed Historic Settlement. Landscape Research, Vol. 34, No. 1, 33-54, Routledge, February 2009.

[11] Guidelines for Landscape and Visual Impact Assessment. Second edition. The Landscape Institute with the Institute of Environmental Management and Assessment. Spon Press Taylor and Francis Group, London and New York 2002, reprinted 2008.

[12] Borys T. (Ed.), 2005. Indicators of sustainable development. Ekonomia I Środowisko. Warszawa - Białystok, 2005.

[13] Hełdak M. 2012 The influence of planning decisions on the changes in the cultural landscape of rural areas - the case of tourist towns in the Bukowina Tatrzańska commune (in print) [in Polish], 2012.

[14] Palmisano J. M. (Ed.), 2000: World of Sociology. Thomson Gale, Farmington Hills, 2000.

[15] Berry, B.J.L., 1976: The counterurbanization process: Urban America since 1970, w Berry, B.J.L. (Ed.): Urbanization and counterurbanization, Sage Publication, Beverly Hills -London, s. 17-30, 1976.

[16] Klaassen L.H., Paelinck J.H.P., 1979: The future of large towns. Environment and Planning A11(10), s. 1095-1104, 1979. 